\title{
Decomposition of labile and recalcitrant litter types under different plant communities in urban soils
}

\section{Vauramo, Saara}

2010

Vauramo , S \& Setälä , H M 2010 , ' Decomposition of labile and recalcitrant litter types under different plant communities in urban soils ', Urban Ecosystems, vol. 14 , no. 1 , pp. 59-70 . https://doi.org/10.1007/s11252-010-0140-9

http://hdl.handle.net/10138/26323

https://doi.org/10.1007/s11252-010-0140-9

submittedVersion

Downloaded from Helda, University of Helsinki institutional repository.

This is an electronic reprint of the original article.

This reprint may differ from the original in pagination and typographic detail.

Please cite the original version. 


\title{
Urban belowground food-web responses to plant community manipulation - Impacts on nutrient dynamics
}

\author{
Saara Vauramo*, Heikki Setälä \\ University of Helsinki, Department of Environmental Sciences, Niemenkatu 73, FIN-15140 Lahti, Finland
}

\section{A R T I C L E I N F O}

\section{Article history:}

Received 6 April 2009

Received in revised form

14 December 2009

Accepted 6 April 2010

Available online $\mathrm{xxx}$

\section{Keywords:}

Urban soil

Ecosystem service

Nutrient dynamics

Energy channel

Plant species diversity

\begin{abstract}
A B S T R A C T
Transformation of soils by urbanization is known to pose drastic effects on the physical, chemical and ecological characteristics of urban soils, which are likely to hamper the important ecosystem services produced by belowground biota. The use of plants in improving/restoring soils is a well established practice in various disturbed ecosystems, but the knowledge of the ability of primary producers to modify urban soils is virtually lacking. To explore the effects of aboveground plant manipulation on belowground biota and soil processes we established a field experiment using four plant species (Lotus corniculatus, Holcus lanatus, Picea abies and Calluna vulgaris) of three functional traits according to their litter quality. The 2.5-year long study applying pan lysimeters to collect water leachates from the rhizospheres was conducted at two urban sites with differing soil characteristics.

Plant species producing labile litter (legume Lotus and grass Holcus) produced a higher bacterial energy channel biomass in comparison to plants (Calluna and Picea) producing recalcitrant litter. The bacterial-dominating energy channel under Lotus plots leached higher amount of inorganic nitrogen than the plots with Calluna and Picea, which had relatively higher proportion of fungal biomass in the soil. However, when the leaching loss was compared to the potentially leachable soil inorganic nitrogen, the most species-diverse mixed communities, albeit increasing the bacterial biomass, showed a highest capacity for conserving nitrogen in the soil. Our study demonstrates the great potential of plant species/functional types to modify the urban belowground communities and consequently, the nutrient dynamics of disturbed urban soils.
\end{abstract}

(c) 2010 Elsevier B.V. All rights reserved.

\section{Introduction}

Compelling evidence shows that the increasing pressure of human activities has drastically altered virtually all of the Earth's ecosystems (Pickett et al., 2001; Vitousek et al., 1997). By the end of this decade, more than half of the world human population will be living in cities and other urbanized areas (UN, 2007). Land-use changes can be seen analogous to soil use changes, as well-developed old soils are replaced by functionally altered soils or even by completely new substrates, called "made lands" (PavaoZuckerman, 2008; Pickett et al., 2001; Pouyat et al., 2002). Such conversion of land and soils to urban use is likely to translate into changes in soil biota, thereby distorting life-supporting ecosystem services, such as decomposition of organic matter and cycling of nutrients (Carreiro et al., 1999; Hooper et al., 2005; Kaye et al., 2005; Pavao-Zuckerman and Coleman, 2005; Pieper and Weigman, 2008; Pouyat et al., 2002; Steinberg et al., 1997).

\footnotetext{
* Corresponding author. Tel.: +358 98922 0332; fax: +358 989220289.

E-mail addresses: saara.vauramo@helsinki.fi, svauramo@gmail.com (S. Vauramo), heikki.setala@helsinki.fi (H. Setälä).
}

Urban ecological studies have traditionally focused on exploring changes in vegetation structure as affected by urban activities (Knapp et al., 2008; Pickett et al., 2001; Thompson and McCarthy, 2008; Williams et al., 2005). However, to predict the consequences of urbanization on the structure and functioning of the entire urban ecosystem, the effects of human pressure on complete food webs must be known (Pickett et al., 2001). For example, our knowledge of the effects of urbanization on ecosystem services is still very limited (Byrne et al., 2008). Cheng et al. (2008a,b) and PavaoZuckerman and Coleman (2007) suggested that urbanization may cause community-level changes in soil biota which may further feed back to ecosystem processes, such as nutrient cycling (Cheng and Grewal, 2009; Pavao-Zuckerman and Coleman, 2005). Scattered evidence shows that populations of soil microbes differ between urban soils and adjacent natural soils (Carreiro et al., 1999; Kaye et al., 2005). This is also true for some representatives of the soil fauna, like earthworms (Steinberg et al., 1997), arthropods (McIntyre et al., 2001), and proturan communities (Christian and Szeptycki, 2004). Altered urban belowground communities can also have measurable effects on ecosystem scale processes; in a study conducted along an urban-to-rural gradient in New York (USA), non-native earthworms present in urban soils were shown 
Table 1

Site characteristics and soil properties (mean \pm S.D.) of the two study sites ( $L F=$ landfill, $C G=$ city garden) at the beginning of the study.

\begin{tabular}{|c|c|c|}
\hline & \multicolumn{2}{|l|}{ Study site } \\
\hline & LF & CG \\
\hline \multirow[t]{2}{*}{ Site coordinates } & $61^{\circ} 0^{\prime} 16.51^{\prime \prime} \mathrm{N}$ & $60^{\circ} 58^{\prime} 12.55^{\prime \prime} \mathrm{N}$ \\
\hline & $25^{\circ} 38^{\prime} 37.1^{\prime \prime} \mathrm{E}$ & $25^{\circ} 38^{\prime} 37.1^{\prime \prime} \mathrm{E}$ \\
\hline Age of the site & $\sim 5$ years & 40 years in urban park use, prior used as farmland \\
\hline Plant communities & Primary succession & Intensively managed \\
\hline Soil type, remarks & Sand and construction materials & Fine silt soil, disturbed by gardening \\
\hline Soil particle size & $0.2-2.0$ & $0.002-0.2$ \\
\hline Conductivity $\left(10 \mathrm{M} \mathrm{s}^{-1} \mathrm{~cm}\right)$ & $1.2 \pm 0.4$ & $1.5 \pm 1.3$ \\
\hline$\% \mathrm{OM}$ & 2 & 9 \\
\hline $\mathrm{pH}$ & $7.6 \pm 0.2$ & $6.3 \pm 0.2$ \\
\hline $\mathrm{NO}_{3} \mathrm{mg}^{-1} \mathrm{~L}$ & 10 & $13 \pm 4.9$ \\
\hline $\mathrm{B} \mathrm{mg}^{-1} \mathrm{~L}$ & $0.2 \pm 0.1$ & $0.4 \pm 0.1$ \\
\hline $\mathrm{S} \mathrm{mg}^{-1} \mathrm{~L}$ & $14.3 \pm 6.8$ & $22.3 \pm 18$ \\
\hline $\mathrm{Mg} \mathrm{mg}^{-1} \mathrm{~L}$ & $86 \pm 17$ & $232 \pm 17$ \\
\hline $\mathrm{K} \mathrm{mg}^{-1} \mathrm{~L}$ & $76.8 \pm 14$ & $125 \pm 7$ \\
\hline Tot. $\mathrm{P} \mathrm{mg}^{-1} \mathrm{~L}$ & $7.4 \pm 3.2$ & $6.4 \pm 0.5$ \\
\hline Ca $\mathrm{mg}^{-1} \mathrm{~L}$ & $1796 \pm 590$ & $2080 \pm 920$ \\
\hline
\end{tabular}

to enhance the turnover rate of soil carbon when compared to rural soils without earthworms (Pouyat et al., 2002; Steinberg et al., 1997).

The formation of soils and the soil organic matter content are critically influenced by the amount and type of vegetation (Wardle, 2002). For example, Bardgett et al.(1999), Grayston et al. (1998) and Marschner et al. (2004) have shown that grassland plants can give rise to varying soil microbial communities depending on the quality and quantity of root exudates and aboveground litter. In theory, plant types (ecophysiological traits sensu Grime, 1974) producing readily decomposable, labile litter should favor a bacterial-based energy channel, while plants producing recalcitrant litter should encourage the formation of a fungal-based energy channel (Moore and Hunt, 1988; Paterson et al., 2008; Wardle, 2002). Furthermore, the bacterial-based energy channel is expected to result in fast energy/material flow, while a slow energy flux and material turnover should be typical in a fungal-dominating system (Coleman et al., 1983; Moore et al., 2005; Paterson et al., 2008; Rooney et al., 2006).

In the present study, we manipulated the composition of aboveground plant communities to test the ability of plant species to create changes in the belowground community composition, thereby impacting on material flows in urban soils. We used plant species (traits) with different litter quality: Picea abies [L] Karst. (a conifer, Pinaceae) and Calluna vulgaris [L] Hull. (a shrub; Ericaceae) as representatives of plants producing recalcitrant litter, Lotus corniculatus L. (a legume, Fabaceae) as a plant producing easily decomposable, labile, litter and Holcus lanatus L. (a grass, Poaceae) as a plant with intermediate litter quality. As the effect of different plant species can vary with soil type (Innes et al., 2004; Marschner et al., 2004), we conducted the experiment at two urban sites with divergent soil types: old farmland/garden soil and new landfill soil. These two soils were selected since urban sprawl increasingly not only affects old farmland soils (comparable to garden soil) (Antrop, 2004), but also produces completely new man-made soils such as landfills (Pavao-Zuckerman, 2008).

We hypothesized:

(I) Plant species/traits (grass and legume) producing intermediate or labile quality litter promote the establishment of a bacterialbased energy/nutrient channel, while plant species producing recalcitrant litter (coniferous tree, shrub) give rise to the establishment of a fungal-based channel.

(II) Bacterial-based above-belowground systems are "leaky", i.e. leach high amount of nutrients and organic carbon while fungal-based above-belowground systems are "conservative", i.e. retain more of the nutrients and organic carbon in the soil.

(III) The effects of plant species on belowground biota and their functioning are more intense in landfill soil lacking the "preurban legacy" (Pavao-Zuckerman, 2008) and therefore the ecological memory (sensu Schaefer, 2009).

\section{Materials and methods}

\subsection{Establishment of experiments}

Two study sites (referred to as landfill (LF) and city garden (CG), see Table 1$)$, situating at a similar distance $(2 \mathrm{~km})$ from the city centre, but differing with regard to soil properties, age, and plant communities, were selected at the city of Lahti, Southern Finland. LF represents a typical young "made land": man-made landfill site filled with coarse sand and construction materials during 2001-2002. The CG site (Lahti City Garden) is an intensively managed garden type site, i.e. an urban green area. CG soil was classified as fine silt with much higher percentage of organic matter (OM) in comparison to the LF-site. CG soil, which has been used for gardening and tree nursing for the last 40 years, and for agronomical practices before that, showed a disturbed horizontal soil structure. The CG soil, in general, also had a higher nutrient content at the beginning of the experiments. Prior to starting the experiment, soil nutrient content (Table 1.) was analyzed at Viljavuuspalvelu Oy (Mikkeli, Finland) from $25 \mathrm{ml}$ homogenized subsamples $(n=3)$ with accredited methods described by Vuorinen and Mäkitie (1955) and Berger and Truog (1939). In this method soil exchangeable calcium, potassium and magnesium, together with extractable phosphorus and sulphur, are extracted $1 \mathrm{~h}$ in acid ammonium acetate $(0.5 \mathrm{M}$ $\mathrm{CH}_{3} \mathrm{COONH}_{4}, 0.5 \mathrm{M} \mathrm{CH}_{3} \mathrm{COOH}, \mathrm{pH}$ of 4.65 , soil: solution $1: 10 \mathrm{v} / \mathrm{v}$ ) and analysed using ICP spectrometer. Boron was extracted in hot water (Berger and Truog, 1939) and measured using ICP spectrometer. Extractable $\mathrm{NO}_{3}-\mathrm{N}$ was determined from soil-water suspension $(1: 2.5 \mathrm{v} / \mathrm{v})$ using nitrate ion-selective electrode (Viljavuuspalvelu Oy, Mikkeli, Finland).

The two sites were subjected to experimental manipulations in June 2004 before constructing differing plant communities in the plots. Before establishing the plant communities, soil from each plant plot area $\left(1 \mathrm{~m}^{2}\right)$ was removed to a depth of $40 \mathrm{~cm}$ for lysimeter installation. A pan lysimeter system was constructed in the soil to collect water leaching through different plant rhizospheres. The lysimeters, placed in the middle of the $1 \mathrm{~m}^{2}$ plot and to a depth of $30 \mathrm{~cm}$, consisted of a plastic box $(36 \mathrm{~cm} \times 26.5 \mathrm{~cm} \times 10 \mathrm{~cm}$ depth $=9540 \mathrm{~cm}^{3}$ ) with a tube attached into one corner allowing 
us to pump the water leachates from the lysimeter. After being placed in the soil, the lysimeters were topped with $30 \mathrm{~cm}$ of homogenized soil previously removed from the plant community plots. Altogether 25 plots per site were established. Before establishing the plant communities, the plots were fenced with a $10 \mathrm{~cm}$ high plastic fence so that about half of the fence was dug into the soil.

After a stabilization period of 10 days, both study sites were subjected to the same plant treatments: (1) coniferous tree and shrub (P. abies and C. vulgaris); (2) herb, leguminous plant (L. corniculatus); (3) grass (H. lanatus); (4) mixed (all plant types in the same plot); and (5) a plant free control (weeded soil). The placing of the plant treatment plots (hereafter "plots"; $N=5$ ) was fully randomized. In late June the plots were seeded either with Lotus seeds (approx. 300 seed per pure Lotus plot; 150 seeds per mixed plot; supplier Suomen Niittykukkasiemen, Finland), or Holcus seeds (3 g per pure Holcus plot; $1 \mathrm{~g}$ per mixed plot, supplier Herbiseed, England). To accelerate the treatment effect of the slow-growing Picea and Calluna, seedlings instead of seeds were planted on the plots. Two to three-year-old Calluna and Picea seedlings were collected from a road bank in a rural area close to Lahti and transferred to the laboratory to wash the roots free from soil. The seedlings were placed in $1 \mathrm{~L}$ pots filled with the soil collected from either of the two study sites to let them to acclimatize to the soil for a period of two weeks before planting into the field. A total of 10 Calluna and 10 Picea seedlings were planted into each coniferous tree and shrub plot, and two Picea and two Calluna seedlings into mixed plots during summer and autumn 2004. The plots were let to develop and mature for one year before initiation of the samplings. The soil above the lysimeters was composed of a similar plant cover as the rest of the plot throughout the study. The plots were carefully weeded every month during the growing seasons to maintain the desired plant treatments.

Mean daily temperature/precipitation in Lahti were: May-August $200514.4^{\circ} \mathrm{C} / 2.53 \mathrm{~mm}$, September-November $20056.9^{\circ} \mathrm{C} / 1.52 \mathrm{~mm}$, May-August $200615.4^{\circ} \mathrm{C} / 1.11 \mathrm{~mm}$ and September-November $20066.9^{\circ} \mathrm{C} / 2.77 \mathrm{~mm}$ (data from the Finnish Meteorological Institute, WMO 02965).

\subsection{Plant biomass, shoot $\mathrm{C} / \mathrm{N}$-ratio, soil organic matter content and $\mathrm{pH}$}

Aboveground biomass of Lotus and Holcus in the study plots was estimated from an area of $24 \mathrm{~cm} \times 31 \mathrm{~cm}$ in November 2006 by cutting the plant shoots at a height of $5 \mathrm{~cm}$ (see Appendix A). The removed plant material was oven dried $\left(>60^{\circ} \mathrm{C}\right.$ for 5 days), and weighed. Aboveground biomasses of Picea and Calluna were measured from the entire plot area in June 2007. Drying and weighing were carried out as described above. For the analysis of total root biomass at the final sampling (November 2006), three soil samples (area $10 \mathrm{~cm}^{2}$ and depth of $15 \mathrm{~cm}$; equaling $\sim 200 \mathrm{~g}$ of fresh soil) per each plot were taken using a corer. The roots in the soil were carefully sorted out in the laboratory, washed free of debris, and dried and weighed similarly to the shoots. Plant shoot C/N-ratio was measured from dried samples using Leco CNS-2000 (Leco Corboration, USA) carbon analyzer. Shoot C/N-ratios of the plants were: 11.6 (Lotus), 24.0 (Holcus), 52.7 (Picea) and 53.8 (Calluna). Soil pH (in $1 \mathrm{M} \mathrm{KCl}$ ) was analyzed according to the ISO 10390:2005 standard (Appendix A). Soil organic matter content (Appendix A) was analyzed from homogenized, oven dried $\left(+90^{\circ} \mathrm{C}, 18 \mathrm{~h}\right)$ samples after being incinerated at $550^{\circ} \mathrm{C}$ for $4 \mathrm{~h}$.

\subsection{Samplings and analyses}

The plots were sampled six times (three times per growing season) during the study period as follows: June 2005 (i.e. one year after establishing the study); August 2005; November 2005; June
2006; August 2006; and October/November 2006 (third fall). In each sampling, three soil cores (diameter of $3 \mathrm{~cm}, 8 \mathrm{~cm}$ deep) were randomly taken from each plot for the analysis of soil nematodes, microarthropods (mites and collembolas) and enchytraeid worms. Soil microbial community structure and biomass was estimated using the PLFA (phospholipid fatty acid) analysis in August 2006. At the last sampling (October/November 2006), analyses of nematode trophic group composition were conducted.

Samples for soil nitrate and ammonium content were taken in August and November 2005 and June 2006, while samples for soil phosphate content in June 2006. Lysimeter samples for nitrate, ammonium and phosphate analysis were taken in August 2005, August 2006, and November 2006. The lysimeters were emptied before the samplings. The samples to be analyzed for nutrients and TOC were then let to accumulate in the lysimeters for a time period of 7 days. TOC in the lysimeter leachates were taken in November 2005 and November 2006. Before being analyzed the samples were stored in $-20^{\circ} \mathrm{C}$.

Extraction of soil nematodes and enchytraeid worms was carried out using the wet funnel method of O'Connor (1967). The extracted nematodes and enchytraeid worms were stored in a cold room and the total number of individuals was counted alive within 2 days. For the analysis of enchytraeid worm biomass, the formula by Abrahamsen (1973) was applied. The trophic group/feeding guild composition (bacterial- and fungal-feeding nematodes, omnivores, predators and plant parasitic nematodes) was analyzed according to the method described by Yeates et al. (1993) from fixed samples (heated and fixed in $40 \%$ ethanol) using a phase contrast microscope with 100 -fold magnification. Soil microarthropods were extracted using a modified high gradient apparatus (Macfadyen, 1961) for 7 days, after which the number of extracted microarthropods was counted under a binocular microscope. Due to the low number of extracted fauna during the first year of the study, data is presented only from November 2005 from both field experiments.

Soil microbial community structure and the fungal and bacterial biomasses were analyzed using the PLFA method by Frostegård et al. (1993) with some modifications by Stoeck et al. (2002). PLFA analysis provides a sensitive (Leckie et al., 2004) and holistic approach to the analysis of microbial communities, but it is unable to detect changes in populations of individual species (Zelles, 1999). Standard nomenclature is used to describe PLFAs (Tunlid and White, 1992). Briefly, we extracted phospholipids from $2 \mathrm{~g}$ of freeze-dried soil, from which roots were carefully removed before freezing. The extracted phospholipids were analyzed with GC-FID (6890N Network GC System, Agilent Technologies) equipped with a $30 \mathrm{~m}$ long low-polar capillary column (ZB-5ms, Phenomenex, Torrance, CA, USA). For the calibration of different methyl esters we used a FAME standard (Supelco, Bellefonte, Pennsylvania, USA) and the fatty acids $13: 0$ and 19:0 were used as internal stan-

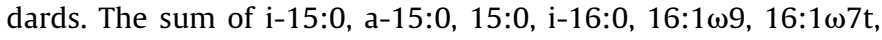

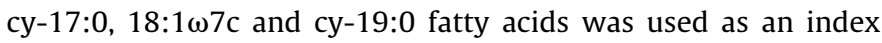

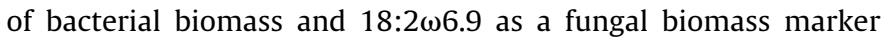

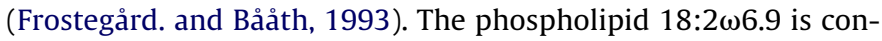
sidered to be predominantly from fungal origin (Frostegård. and Bååth, 1993; Klamer and Bååth, 2004). Fungal to bacterial biomass was calculated as nmol fungal PLFA (nmol g-1 OM d.w.):nmol sum of bacterial PLFAs (nmol g-1 OMd.w.). The biomass of arbuscular mycorrhizal (AM) fungi was determined using fatty acid 16:1 $1 \omega 5$ (nmol g-1 OM d.w.) (Olsson et al., 1995; Olsson, 1999), but as it was not included into the biomass estimation of fungi (Olsson et al., 1995), total microbial biomass was calculated as a sum of bacterial, fungal and AM-fungal biomass markers.

Potentially leachable, extractable nutrients (soil and water leachates) were analysed colorimetrically using QuickChem 8000 analyzer (Lachat Instruments). $\mathrm{NO}_{3}{ }^{-}$and $\mathrm{NH}_{4}{ }^{+}$in soil samples were 
extracted with $1 \mathrm{M} \mathrm{KCl}(10 \mathrm{~g}$ of soil in $50 \mathrm{ml}$ of $1 \mathrm{M} \mathrm{KCl})$ after being shaken for $3 \mathrm{~h}$ in a planar shaker (Lachat method 12-107-04-1-E). $\mathrm{PO}_{4}{ }^{3-}$ in soil samples was extracted in a similar manner except that distilled water was used instead of $\mathrm{KCl}$ (Lachat method 10-115-011-B). Before analysis, the samples were filtered through cellulose filter papers (Whatman S\&S 597 and $589^{3}$ ) to remove soil particles. Appropriate filtering controls and blank controls were produced. Total organic carbon (TOC) of lysimeter water samples was analyzed according to the SFS-EN-1484 standard method using Apollo 9000 TOC analyzer (Teledyne Tekmar).

Using the data of soil extractable nutrients we estimated how much of the potentially available inorganic $\mathrm{N}$ in the soil did leach on a daily basis. An approximation of $20 \mathrm{~kg}$ soil mass per $\mathrm{m}^{2}$ (plot area) was applied. We compared the soil inorganic nitrogen content in August 2005 with the losses of inorganic $\mathrm{N}$ from the same period. Due to the lack of the soil nutrient data in August and November 2006, we applied the soil nutrient data collected in June 2006 as a reference to the leaching data from August and November 2006.

\subsection{Biomasses of the energy channels}

To explore whether the different plant communities give rise to divergent resource use channels in the rhizosphere, we quantified the biomass of $\mathrm{C}$ ( $\mu \mathrm{gg}^{-1} \mathrm{OM}$ dry weight) in the following energy channels: fungal (fungi- and fungal-feeding nematodes), bacterial (bacteria and bacterial-feeding nematodes) and root (root feeding nematodes). To convert nematode numbers to biomass (ng C per worm), the data by Neher et al. (2004) was applied. The data by Klamer and Bååth (2004) was used to convert PLFA 18:2 $\omega 6.9$ to fungal biomass $C$ and the data by Bååth and Anderson (2003) to convert sum of bacterial PLFAs to bacterial biomass C. Omnivorous species (enchytraeids, omnivorous nematodes), predators, and groups with very few observations (microarthropods) were not included in the analysis.

\subsection{Statistical analysis}

The experimental set-up followed of a three-factor design with "Plant treatment" and "Soil type (LF or CG)" as fixed factors, and Time as a repeated factor. Due to the often heterogeneous variances and abnormal distribution of the data, a non-parametric two-factor Kruskall-Wallis test was applied (Ranta et al., 1989). The effects of the factors "Plant treatment" and "Soil type" were tested separately for each sampling time, because Time (as a repeated factor) cannot be properly taken into account in a non-parametric test.

To correct $\alpha$-inflation due to multiple testings, the false discovery rate (FDR) method was applied. This method controls the fraction of wrong rejections of null hypotheses among all rejected hypotheses (Benjamini and Hochberg, 1995). The FDR approach has been suggested to have several advantages over classical familywise error rate (FWER, such as Bonferroni) approaches in studies tackling problems of multiple testing (García, 2004; Jiménez et al., 2008; Waite and Campbell, 2006). We controlled the FDR rate at 0.05 level and included analyses of all main effects on the same table (Tables B1-B3). To calculate exact $p$-values for $\alpha$-level correction, a one-way Kruskall-Wallis test was performed when only one factor had a significant main effect on a given variable in the two-factorial model. Ranked $k$ (" $k$ "), i.e. the FDR-calculated minimum $p$-value for rejection of null hypothesis, was 0.017 . Pair-wise comparisons were performed when the $p$-value of the main (general) effect was below 0.017. We used a non-parametric Tukey test (Ranta et al., 1989) after a two-factorial Kruskall-Wallis test, or, a Mann-Whitney $U$ test in conjunction with one-way Kruskall-Wallis test. Results of the post hoc tests were interpreted as significant when $p \leq 0.05$.
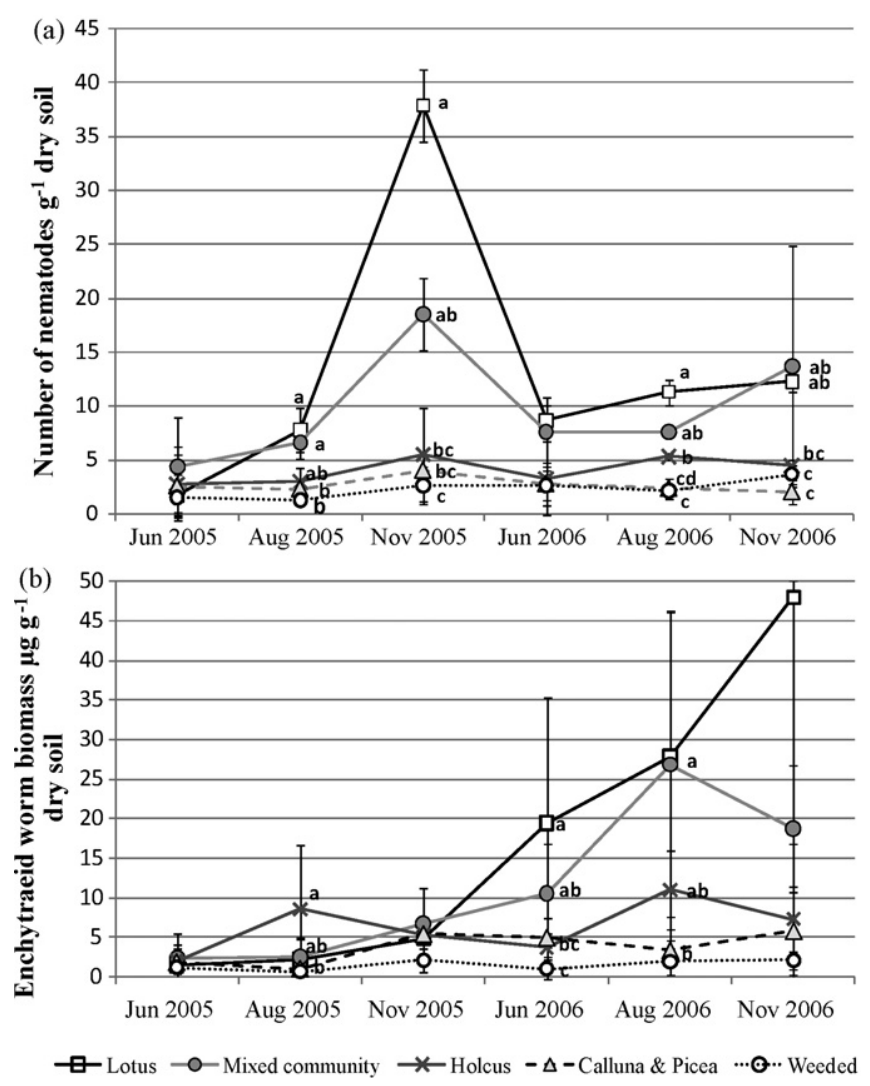

Fig. 1. (a) Number of soil nematodes (mean \pm S.D.) and (b) the biomass of enchytraeid worms ( $\mu \mathrm{g} \mathrm{g}^{-1}$ dry soil; mean \pm S.D.) under different plant treatments at the six samplings. Data combines results from both study sites. Different letters indicate differences (non-parametric Tukey test; $p<0.05$ ) between plant treatments within the sampling.

\section{Results}

\subsection{Plant effects on belowground communities}

\subsubsection{Nematode abundance and trophic group structure}

Plant treatment imposed a significant main effect on nematode abundance in August and November samplings 2005-2006 (Table B1), regardless of soil type. Calluna and Picea plots and bare soil plots had significantly less nematodes than Lotus plots (Fig. 1a.). However, in June 2005 and 2006 soil type had a significant effect on soil nematodes so that CG soil plots had significantly higher number of nematodes than plots in LF soil irrespective of the plant treatment (Table B1). The number of bacterial-feeding, plant parasitic and predatory nematodes was affected by plant treatment while omnivorous nematodes were influenced by soil type. Fungalfeeding nematodes were affected by neither of the treatments (Table B1). Bacterivorous and plant parasitic nematodes were more abundant in Lotus and mixed community plots when compared to Calluna and Picea plots $(p<0.05)$ (Fig. 2.). Lotus plots also had significantly more bacterivorous nematodes than Holcus or weeded plots $(p<0.05)$. In comparison to the weeded plots, Lotus $(p<0.01)$, Holcus $(p<0.01)$ and mixed community plots $(p<0.05)$ had a higher abundance of predatory nematodes. The LF soil had a significantly higher $(p<0.01)$ abundance (about 1.3 individ. $\mathrm{g}^{-1}$ dry soil) of omnivorous nematodes than CG soil (about 0.3 individ. $\mathrm{g}^{-1}$ dry soil) (Table B1).

\subsubsection{Biomass of enchytraeid worms}

Plant treatment had a significant effect on the biomass of enchytraeid worms in four out of the six samplings (Table B1 and Fig. 1b) In November 2006, the effect of plant treatment was dependent on 


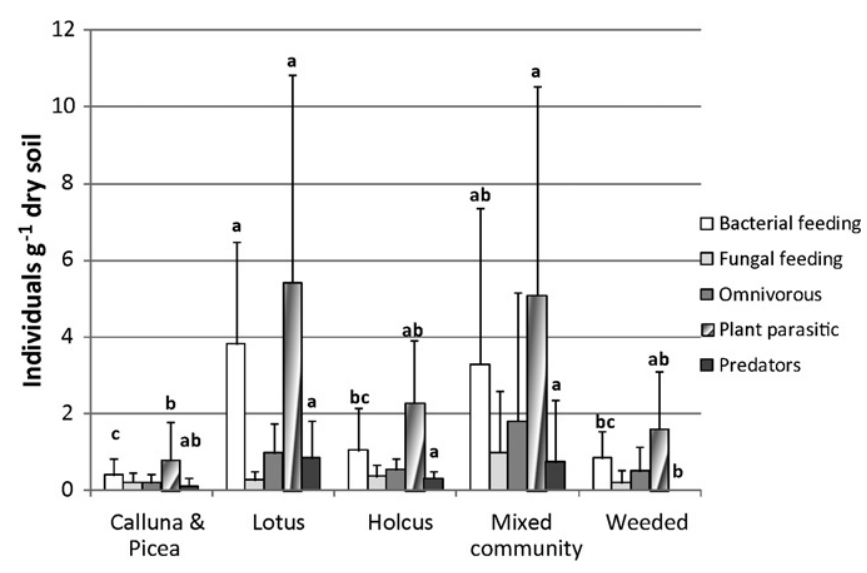

Fig. 2. The number of nematodes (individuals $\mathrm{g}^{-1}$ dry soil; mean + S.D.) belonging to different feeding groups under different plant treatments at the end (November 2006) of the experiment. Bars sharing the same letter are not significantly different $(p<0.05)$ between plant treatments using non-parametric Tukey test. Data combines results from both experimental sites.

the soil type: in LF soil, plant treatment exerted a highly significant effect on enchytraeid worm biomass $(H=15.04$, d.f. $=4, p=0.0015)$, while in CG soil enchytraeid worms were equally abundant across the plant communities.

In August 2005, Holcus plots had a significantly higher enchytraeid worm biomass than in Calluna and Picea, Lotus or bare soil plots. In June and August 2006, the beneficial effect of leguminous plants on enchytraeid worms became clear: Lotus and mixed community plots had more enchytraeid worms than the Calluna and Picea, or the weeded plots. In the last sampling (November 2006) in LF soil, all plots containing legume (Lotus and mixed community) had a larger $(p<0.05)$ enchytraeid worm biomass than Calluna and Picea, Holcus or weeded plots (data not shown).

\subsubsection{Number of soil microarthropods}

Plant treatment showed a significant effect on the number of soil collembolans and mites in both soil types in November 2005 (Table B1). Calluna and Picea and weeded plot treatments had significantly less collembolans than Lotus or mixed community treatments (Appendix E). The number of mites was significantly lower in weeded plots compared to soils with a mixed plant community. Plant effects were not affected by the soil type.

\subsubsection{Microbial community analysis}

Plant treatment exerted a significant influence on soil bacteria (the sum of bacterial PLFAs) and AM-fungi (16:1 $1 \omega 5$ ), while soil

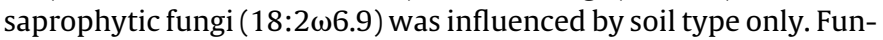
gal to bacterial ratio was affected both by plant treatment and soil type. Total microbial biomass (the sum of all microbial PLFAs) did not respond to the two treatments (Table B2). Plant effects were not affected by the soil type.

Lotus plots had significantly more bacterial PLFAs in the rhizosphere in comparison to Calluna and Picea, or bare soil plots. Lotus, Holcus and mixed plant communities had a significantly higher quantity of AM-fungal biomarker compared to Calluna and Picea plots. However, the fungi to bacteria-ratio in Calluna and Picea plots was significantly higher than that of to the other plant treatments $(p<0.05)$.

Plots in LF soil had an average 50\% more fungal PLFA (calculated per gram of soil organic matter) and thus approximately $40 \%$ higher fungi to bacteria-ratio than plots in CG soil (Fig. 3). The quantity of PLFA biomarkers chosen to represent different microbial groups ranged from 95 to 300 (bacteria), 5.5 to 73 (fungi) and 10 to 70 (AM-fungi) $\mathrm{nmol} \mathrm{g}^{-1}$ organic matter.

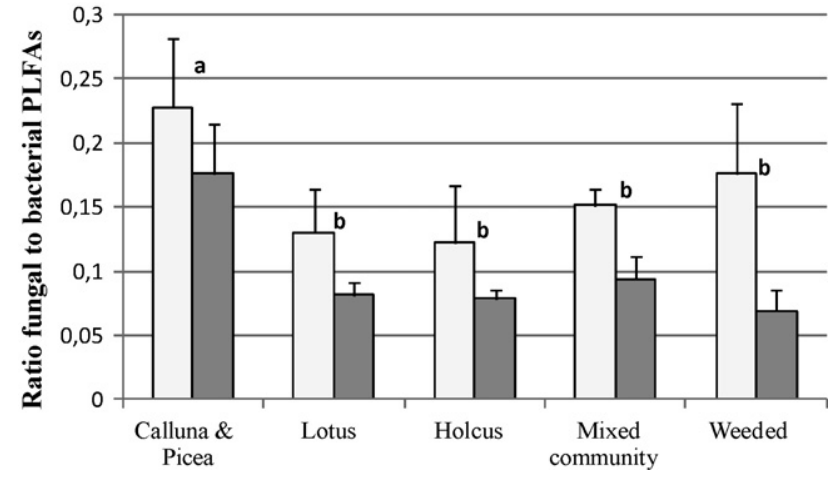

Fig. 3. Soil fungal:bacterial biomass-ratio (mean + S.D.) for LF (open columns) and CG (solid columns) in August 2006. Different letters indicate differences between plant treatments (statistics calculated from both experimental sites; nonparametric Tukey test; $p<0.05$ ).

\subsubsection{Biomass of the energy channels}

The biomass of the bacterial channel was influenced by the plant treatment, and the biomass of the fungal channel by the soil type. The biomass of the root channel was affected by both plant and soil treatment (Table B2). Lotus and Holcus had a significantly higher bacterial biomass than Calluna and Picea or bare soil plots $(p<0.05)$ (Fig. 4.). Mixed community plots had a higher biomass of root energy channel than Calluna and Picea, Holcus or bare soil plots $(p<0.01)$, while Lotus plots had a higher root energy channel biomass as compared to Calluna and Picea or bare soil plots $(p<0.01)$. LF soil had significantly $(p<0.001)$ larger biomass of the fungal and root energy channels than CG soil.

\subsection{Plant effects on soil nutrient dynamics}

\subsubsection{Soil nutrient content}

Plant treatment imposed significant effects on soil ammonium and nitrate content in June 2006, while soil ammonium and nitrate content in August 2005 and phosphate content in June 2006 was affected by soil type only (Table B3). Plant treatment and soil type exerted significant effects on soil ammonium and nitrate content in November 2005 (Table B3). Plant treatment effects on soil nutrient content were not dependent on soil type.

In November 2005, soil under Lotus plants was significantly higher in ammonium and nitrate than in Calluna and Picea, Holcus or

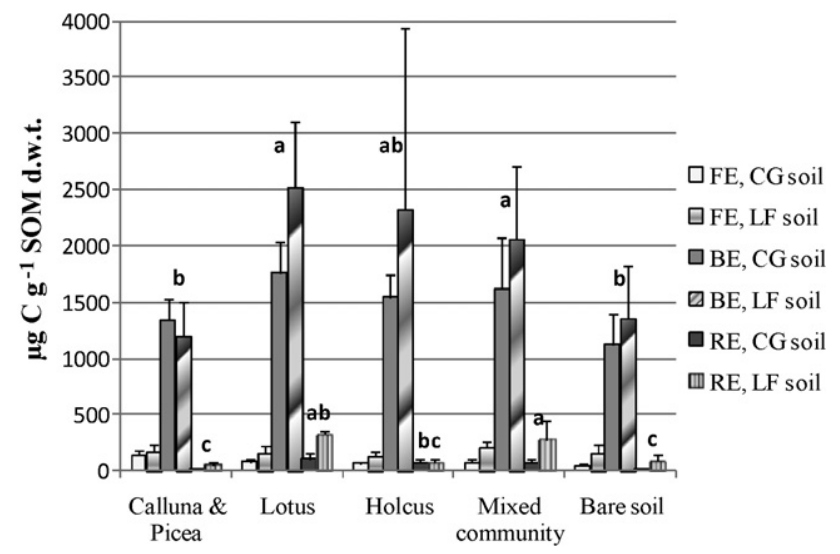

Fig. 4. Biomass ( $\mu \mathrm{gCg}^{-1} \mathrm{SOM}$ dry weight, mean + S.D.) of the three energy channels at the two study sites (CG and LF) in August 2006. FE = fungal energy channel (biomass of fungi- and fungal-feeding nematodes), $\mathrm{BE}=$ bacterial energy channel (biomass of bacteria and bacterial-feeding nematodes), $\mathrm{RE}$ = root energy channel (biomass of root feeding nematodes). Different letters indicate differences between plant treatments (non-parametric Tukey test; $p<0.05$ ) separately for different energy channels. Data combines results from both study sites. 
weeded soils $(p<0.05)$ (Appendix C). In June 2006, Lotus and mixed community plots had significantly higher $(p<0.05)$ soil nitrate content than Calluna and Picea, Holcus or weeded plots. Lotus and mixed community plots had also significantly higher soil ammonium content than weeded plots $(p<0.01)$ in June 2006. Plots growing Holcus contained significantly more soil ammonium than weeded plots $(p<0.05)$ in June 2006. CG soil had a constantly higher nutrient content in comparison to LF soil (Appendix C).

\subsubsection{Leaching of nutrients and organic carbon (TOC) from the} soil

Plant treatment had a significant impact on leaching of nitrate (August 2005) and ammonium (November 2006), while leaching of ammonium in August 2005, nitrate in November 2005 and phosphate (August 2005, August 2006 and November 2006) were influenced by soil type only (Table B3). Both plant treatment and soil type had a significant effect on nitrate leaching in August 2006. Leaching of organic carbon was affected neither by plant treatment nor soil type.

Plant treatment imposed a significant effect on the proportional leaching loss of soil inorganic nitrogen in August 2006, while in November 2006 only soil type had an effect (Table B3): the proportion of soil inorganic $\mathrm{N}$ lost by leaching from the potentially leachable soil inorganic N pool in August 2005 was affected by plant treatment and soil type. Plant treatment effects on any of the leaching loss parameters were independent of soil type.

In August 2005, Calluna and Picea and weeded plots leached significantly $(p<0.05)$ more nitrate than Holcus or mixed community plots (Fig. 5a.). Weeded plots also had higher nitrate leaching losses than Lotus plots at that time $(p<0.05)$. The proportion of soil inorganic N lost by leaching in August 2005 was significantly higher in weeded plots than in plots with plant cover $(p<0.05)$ (Fig. $5 c)$. In August 2006, a significantly higher amount of nitrate leached from Lotus plots in comparison to other plots $(p<0.01)$. Proportionally, weeded soils lost significantly higher amounts of soil inorganic $\mathrm{N}$ in August 2006 than Calluna and Picea plots $(p<0.05)$ or mixed communities $(p<0.01)$. In November 2006, the amount of ammonium leached from Lotus and mixed community plots was significantly higher than that from Calluna and Picea plots $(p<0.05)$ (Fig. 5b). In general, leaching of inorganic nitrogen $\left(\mathrm{NO}_{3}{ }^{-}+\mathrm{NH}_{4}{ }^{+}\right)$and phosphorus $\left(\mathrm{PO}_{4}{ }^{3-}\right.$, Appendix D) was higher from CG soil than from LF soil. Neither plant treatment nor soil type had an effect on the leaching of organic carbon in August 2005 or 2006 (Table B3).

\section{Discussion}

Soil food-web structure is believed to respond slowly to changes in plant community composition (Bardgett et al., 2005; Holtkamp et al., 2008). However, our results demonstrate a clear feedback of soil food-web structure to vegetation manipulation within a time period of less than 3 years. To our knowledge, this is the first study of its kind in which the ability of plants to modify almost the entire urban belowground food web and the key ecosystem services (nutrient cycling) has been explored.

\subsection{Labile and recalcitrant litter producing plants enforce the development of different energy channels}

The basal level of belowground decomposer food webs was clearly bacterial-dominated irrespective of the plant treatment and soil type (71-86\% of the total biomass $C$ of the energy channels consisted of bacteria), which supports the observed adverse effects of urbanization on fungal biomass (McDonnell et al., 1997). Supporting our first hypothesis, the bacterial energy channel biomass was larger in plant plots producing labile or intermediate quality litter (Lotus and Holcus and mixed community plots) in comparison to
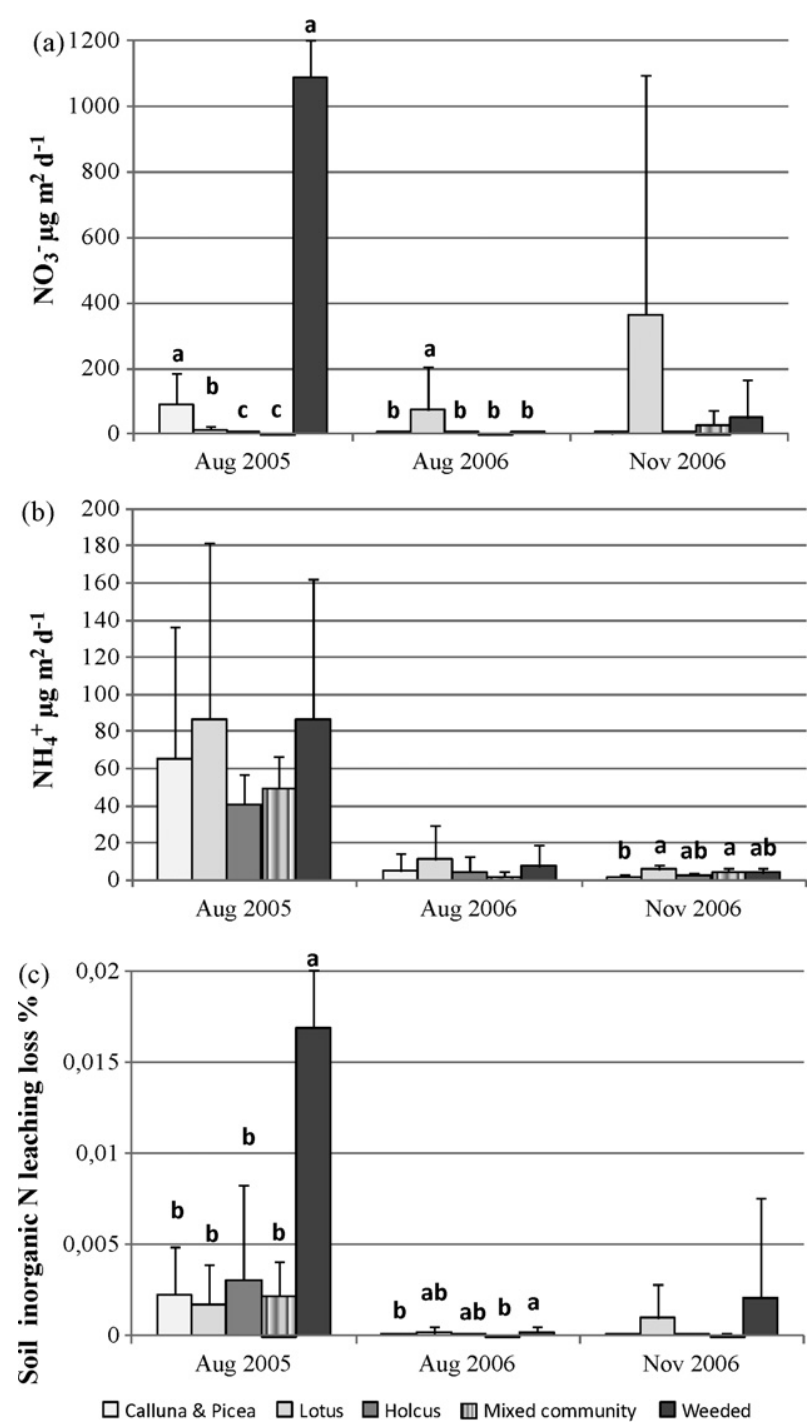

Fig. 5. Leaching of (a) nitrate $\left(\mu \mathrm{g} \mathrm{m}^{2} \mathrm{day}^{-1}\right.$, mean + S.D.) and (b) ammonium $\left(\mu \mathrm{g} \mathrm{m}^{2} \mathrm{day}^{-1}\right.$, mean + S.D. $)$ and (c) soil daily inorganic nitrogen leaching loss $\%$ (leaching loss of nitrate + ammonium $\mu \mathrm{g} \mathrm{m}^{2} \mathrm{day}^{-1} /$ soil nitrate + ammonium content; mean +S.D.) from the rhizosphere of the different plant communities at three sampling times. Different letters indicate differences (non-parametric Tukey test; $p<0.05$ ) between plant treatments within a sampling time. Data combines results from the two study sites. The amount (mean \pm S.D.) of nitrate leached through the soil weeded soil in November 2005 was $1090 \pm 1300 \mu \mathrm{g} \mathrm{m}^{2}$ day $^{-1}$.

Calluna and Picea and bare soil plots. Contrasting to our hypothesis, plants producing recalcitrant litter (Calluna and Picea), did not boost the development of fungal biomass within our experimental time constrain. Because the production of aboveground litter by the young seedlings of Calluna and Picea was observed to be negligible, the litter degrading saphrotrophic fungi three years after establishment of the experiments was probably of little importance. The increased fungal to bacterial (PLFA) biomass-ratio in Calluna and Picea plots can be merely explained by the relatively low quantity of bacteria under these plants. However, when the systems with plants producing recalcitrant litter mature, the biomass of specialized saphrotrophic fungi and root symbiont fungi is likely to increase. Noteworthy, the higher quantity of AM (arbuscular mycorrhiza) fungal PLFA marker in Lotus, Holcus and mixed community plots in comparison to Calluna and Picea, indicated also fungal community-level selection (successful mycorrhizal colonization) by the grass and the legume. Given these slight but consistent changes in the soil microbial community composition, the theory of 
distinct energy channels promoted by different plant types (Moore and Hunt, 1988; Wardle, 2002) seems to hold also in strongly disturbed urban soils.

Coniferous tree and shrub (Calluna and Picea) plots had a low number of soil collembolans and mites in comparison to Lotus and mixed community plots in November 2005. The very low numbers of soil microarthropods (also at the end of the study) suggests that either soil microarthropod assemblages do not uniformly respond to plant biota manipulation, or, it takes a substantially longer time for the communities to establish after disturbance (Kardol et al., 2009). The slow recovery rate of soil microarthropods is due to, e.g. lower reproduction rates than that of nematodes and enchytraeid worms (Siepel, 1994).

The clear positive effect of leguminous plants on the abundance of different groups of soil fauna is not strictly explained by their expected food resource, i.e. soil microbes. In contrast to other studies (Spehn et al., 2000; Wardle et al., 2003), microbial biomass was insensitive to plant manipulation in our study. In our study, microbial biomass did not correlate with root or shoot (litter) production. The quantity of bacterial biomarkers was, however, significantly higher in Lotus plots in comparison to Calluna and Picea or weeded plots, which may explain the higher amount of soil nematodes and enchytraeids under legumes. That Lotus plots had a more numerous community of bacterivorous nematodes than Holcus plots indicates a greater importance of the bacterial-based energy channel under legumes than grasses. That plant species identity can have a control on the community composition of nematodes at lower trophic positions has recently been shown by De Deyn et al. (2004) and Viketoft et al. (2009).

Although some differences in soil microbiota between the two soils were observed, the plant treatment effects on other groups of organisms were very similar in both soils over-riding the soil type differences. This contradicts our third hypothesis of the relatively stronger impacts of plant species in strongly artificial soils than in more developed soils.

\subsection{Ability of the soils to retain nutrients and organic $C$}

Irrespective of the plant treatment, the amount of nitrogen leached through the soils was relatively high even 14 months after the establishment of the study, indicating a long-lasting impact of soil disturbance due installation of lysimeters. As expected, the content of inorganic nitrogen increased particularly in soils growing leguminous plants. However, the plots growing N-fixing Lotus also had a high aboveground biomass at the beginning of the study, which apparently resulted in significantly lowered leaching losses in comparison to Calluna and Picea and bare soil plots with much lower aboveground biomass and thus presumably lower growth rate.

The effects of the plants on nutrient dynamics became truly visible two years after the establishment of the study when, as was hypothesized, nitrate leaching losses became higher from Lotus plots than in the other plots. Similar to nitrate, the loss of ammonium from the plots with Lotus at that time (in November 2006) was significantly higher when compared to Calluna and Picea plots. However, estimation of the relative proportion of soil inorganic nitrogen leached from the different plant-soil systems revealed that the most species-diverse mixed communities with a relatively larger proportion of bacteria in their rhizosphere than under Calluna and Picea plots had also a high N-retention capacity, which contradicts our second hypothesis. This indicates that the plants lacking the ability to fix $\mathrm{N}$ (Holcus, Calluna and Picea) and capable of preserving nitrogen in the soil were nitrogen-limited. Thus these $\mathrm{N}$-conservative plants greatly enhanced the retention of inorganic nitrogen in mixed communities with "leaky" leguminous plant.

It may well be that the duration of the experiment was too short to reveal the full potential that plants may have in modifying urban soils. Nevertheless, our study demonstrates that strongly disturbed urban soils having no or little previous contact to primary producers were sensitive to plant species (trait) variation and highlights the consequences for the nutrient dynamics of the system. Importantly, the ability of the plants to control the development of urban soils was virtually independent of the physico-chemical structure of the urban soil. Our findings encourage considering plant traits as functional components in urban green space planning when soil quality is to be improved after negative urbanization impacts (Cheng and Grewal, 2009; Lorenz and Lal, 2009; McDonnell et al., 1997). Further, the impacts of plants on belowground communities and functions were shown to be highly trait/species-specific. This warrants further research as it is by far not clear whether these plant-mediated effects are able to counterbalance (or enhance) the urbanization effects on soils in the long run.

\section{Acknowledgements}

We thank Aleksi Mäntylä for his contribution throughout the study, Tuukka Ryynänen and Tero Fingerroos for their help in the establishment of the experiment, Anu Liukkonen for assistance in the PLFA analysis and Heidi Rasikari for proof-reading the manuscript. We are grateful to the University of Helsinki and Onni ja Hilja Tuovinen Foundation for funding the study.

\section{Appendix A.}

See Table A1.

\section{Appendix B. Results of the statistical tests}

See Tables B1-B3.

\section{Appendix C.}

See Table C1.

Table A1

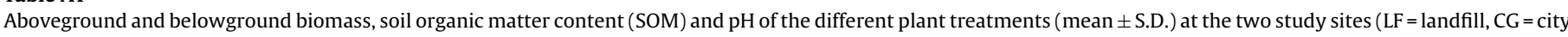
garden) in the end of the experiment.

\begin{tabular}{|c|c|c|c|c|c|}
\hline Study site & Plant treatment & Aboveground biomass ( $\mathrm{g}^{-1}$ d.w. $\mathrm{m}^{2}$ ) & Belowground biomass ( $\mathrm{g}^{-1}$ d.w. $\mathrm{m}^{2}$ ) & SOM & Soil pH \\
\hline \multirow[t]{5}{*}{ LF } & Calluna and Picea & $81.64 \pm 11.2$ & $1544.0 \pm 1911.9$ & $5.1 \pm 0.0$ & $6.6 \pm 0.5$ \\
\hline & Lotus & $812.10 \pm 228.4$ & $118.2 \pm 64.8$ & $5.0 \pm 0.0$ & $6.6 \pm 0.3$ \\
\hline & Holcus & $35.49 \pm 17.4$ & $935.9 \pm 387.3$ & $4.2 \pm 0.0$ & $6.3 \pm 0.0$ \\
\hline & Mixed community & $449.8 \pm 202.7$ & $479.4 \pm 322.6$ & $5.5 \pm 0.1$ & $6.4 \pm 0.2$ \\
\hline & Weeded & $1.3 \pm 0.9$ & $24.3 \pm 18.3$ & $3.8 \pm 0.1$ & $6.1 \pm 0.3$ \\
\hline \multirow[t]{5}{*}{ CG } & Calluna and Picea & $251.2 \pm 75.3$ & $607.1 \pm 255.2$ & $10.4 \pm 0.0$ & $5.1 \pm 0.1$ \\
\hline & Lotus & $694.5 \pm 285.5$ & $259.9 \pm 86.5$ & $11.1 \pm 0.0$ & $5.2 \pm 0.1$ \\
\hline & Holcus & $108.1 \pm 42.0$ & $560.7 \pm 215.8$ & $9.2 \pm 0.0$ & $5.0 \pm 0.2$ \\
\hline & Mixed community & $460.0 \pm 170.3$ & $357.1 \pm 117.4$ & $10.0 \pm 0.0$ & $5.1 \pm 0.1$ \\
\hline & Weeded & $3.9 \pm 3.1$ & $308.6 \pm 108.1$ & $12.1 \pm 0.0$ & $5.1 \pm 0.1$ \\
\hline
\end{tabular}


Table B1

Main effects of the factors "plant treatment" $(\mathrm{P})$, "soil type" $(\mathrm{S})$ and the interaction term "plant type $\times$ soil type" $(\mathrm{P} \times \mathrm{S})$ on the abundance of various groups of soil fauna.

\begin{tabular}{|c|c|c|c|c|c|c|c|c|c|c|c|}
\hline Sampling time & Factor & d.f. & $\begin{array}{l}\text { No. of } \\
\text { nematodes }\end{array}$ & $\begin{array}{l}\text { Bacterial-feeding } \\
\text { nematodes }\end{array}$ & $\begin{array}{l}\text { Fungal-feeding } \\
\text { nematodes }\end{array}$ & $\begin{array}{l}\text { Omnivorous } \\
\text { nematodes }\end{array}$ & $\begin{array}{l}\text { Plant parasitic } \\
\text { nematode s }\end{array}$ & $\begin{array}{l}\text { Predatory } \\
\text { nematodes }\end{array}$ & $\begin{array}{l}\text { Enchytraeids worm } \\
\text { biomass }\end{array}$ & $\begin{array}{l}\text { No. of } \\
\text { collembolas }\end{array}$ & $\begin{array}{l}\text { No. of } \\
\text { mites }\end{array}$ \\
\hline \multicolumn{12}{|c|}{ Degrees of freedom (d.f.) and Kruskall-Wallis H-values } \\
\hline \multirow[t]{3}{*}{ June 2005} & $\mathrm{P}$ & 4 & 2.96 & & & & & & 0.84 & & \\
\hline & $\mathrm{S}$ & 1 & $34.37^{* *}$ & & & & & & 3.74 & & \\
\hline & $\mathrm{P} \times \mathrm{S}$ & 4 & 1.97 & & & & & & 1.32 & & \\
\hline \multirow[t]{3}{*}{ August 2005} & $\mathrm{P}$ & 4 & $29.99^{* *}$ & & & & & & $11.21^{*}$ & & \\
\hline & $\mathrm{S}$ & 1 & 3.76 & & & & & & 1.95 & & \\
\hline & $\mathrm{P} \times \mathrm{S}$ & 4 & 0.69 & & & & & & 2.14 & & \\
\hline \multirow[t]{3}{*}{ November 2005} & $\mathrm{P}$ & 4 & $28.38^{* *}$ & & & & & & 8.65 & $25.96^{* *}$ & 14.24 \\
\hline & $\mathrm{S}$ & 1 & 1.66 & & & & & & 0.27 & 0.88 & 0.26 \\
\hline & $\mathrm{P} \times \mathrm{S}$ & 4 & 3.07 & & & & & & 5.56 & 5.48 & 5.54 \\
\hline \multirow[t]{3}{*}{ June 2006} & $\mathrm{P}$ & 4 & 9.84 & & & & & & $11.86^{*}$ & & \\
\hline & $\mathrm{S}$ & 1 & $11.01^{*}$ & & & & & & 0.48 & & \\
\hline & $\mathrm{P} \times \mathrm{S}$ & 4 & 2.34 & & & & & & 2.24 & & \\
\hline \multirow[t]{3}{*}{ August 2006} & $\mathrm{P}$ & 4 & $36.87^{* *}$ & & & & & & $13.08^{*}$ & & \\
\hline & $S$ & 1 & 0.34 & & & & & & 1.18 & & \\
\hline & $\mathrm{P} \times \mathrm{S}$ & 4 & 1.74 & & & & & & 2.93 & & \\
\hline \multirow[t]{3}{*}{ November 2006} & $P$ & 4 & $24.07^{* *}$ & $17.25^{*}$ & 3.41 & 11.0 & $14.42^{*}$ & $19.28^{* *}$ & 11.0 & & \\
\hline & $S$ & 1 & 3.12 & 3.8 & 2.17 & $10.0^{*}$ & 0.00 & 0.89 & 0.71 & & \\
\hline & $\mathrm{P} \times \mathrm{S}$ & 4 & 2.98 & 0.99 & 1.82 & 0.97 & 6.1 & 0.53 & $14.57^{*}$ & & \\
\hline
\end{tabular}

${ }^{*} p=0.017-0.001$

** $p<0.001$.

Table B2

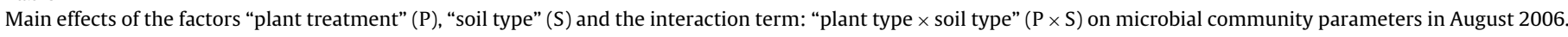

\begin{tabular}{|c|c|c|c|c|c|c|c|c|c|}
\hline Factors & d.f. & $\begin{array}{l}\text { SUM of microbial } \\
\text { PLFAs }\end{array}$ & $\begin{array}{l}\text { SUM of bacterial } \\
\text { PLFAs }\end{array}$ & $\begin{array}{l}\text { Fungal PLFA } \\
18: 2 \omega 6,9\end{array}$ & $\begin{array}{l}\text { Ratio fungal to } \\
\text { bacterial PLFAs }\end{array}$ & $\begin{array}{l}\text { AM-fungal PLFA } \\
16: 1 \omega 5\end{array}$ & $\begin{array}{l}\text { Fungal channel } \\
\text { biomass C }\end{array}$ & $\begin{array}{l}\text { Bacterial channel } \\
\text { biomass C }\end{array}$ & $\begin{array}{l}\text { Root channel } \\
\text { biomass C }\end{array}$ \\
\hline \multicolumn{10}{|c|}{ Degrees of freedom (d.f.) and Kruskall-Wallis H-values } \\
\hline $\mathrm{P}$ & 4 & 2.26 & $13.45^{*}$ & 6.48 & $18.32^{*}$ & $13.33^{*}$ & 6.44 & $15.79^{*}$ & $21.65^{* *}$ \\
\hline S & 1 & 5.93 & 2.50 & $15.89^{* *}$ & $15.59^{* *}$ & 3.36 & $20.35^{* *}$ & 3.36 & $11.20^{* *}$ \\
\hline $\mathrm{P} \times \mathrm{S}$ & 4 & 1.42 & 5.42 & 4.02 & 3.13 & 6.22 & 3.08 & 4.98 & 3.10 \\
\hline
\end{tabular}

${ }^{*} p=0.017-0.001$.
$p<0.001$.

\section{Table B3}

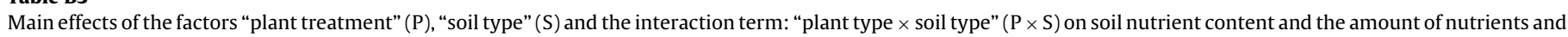

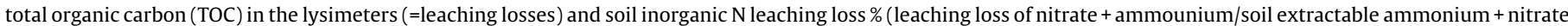
content).

\begin{tabular}{|c|c|c|c|c|c|c|c|c|c|c|}
\hline Sampling time & Factor & d.f. & Soil $\mathrm{NO}_{3}$ & Soil $\mathrm{NH}_{4}$ & Soil $\mathrm{PO}_{4}^{3-}$ & Lysimeters $\mathrm{NO}_{3}^{-}$ & Lysimeters $\mathrm{NH}_{4}^{+}$ & Lysimeters $\mathrm{PO}_{4}^{3-}$ & $\begin{array}{l}\text { Lysimeters } \\
\text { TOC }\end{array}$ & $\begin{array}{l}\text { Soil Inorganic N } \\
\text { leaching (\%) }\end{array}$ \\
\hline \multicolumn{11}{|c|}{ Degrees of freedom (d.f.) and Kruskall-Wallis H-values } \\
\hline \multirow[t]{3}{*}{ August 2005} & $\mathrm{P}$ & 4 & 6.73 & 0.64 & & $18.22^{*}$ & 3.04 & 6.95 & 8.16 & $12.49^{*}$ \\
\hline & $\mathrm{S}$ & 1 & $32.43^{* *}$ & $36.29^{* *}$ & & 0.81 & 6.2 & $6.97^{*}$ & 1.66 & $6.77^{*}$ \\
\hline & $\mathrm{P} \times \mathrm{S}$ & 4 & 1.44 & 1.21 & & 0.88 & 2.41 & 7.93 & 7.93 & 7.15 \\
\hline \multirow[t]{3}{*}{ November 2005} & $\mathrm{P}$ & 4 & $1939^{* *}$ & $18.83^{* *}$ & & & & & & \\
\hline & $\mathrm{S}$ & 1 & $19.39^{* *}$ & $7.6^{*}$ & & & & & & \\
\hline & $\mathrm{P} \times \mathrm{S}$ & 4 & 3.8 & 4.41 & & & & & & \\
\hline \multirow[t]{3}{*}{ June 2006} & $\mathrm{P}$ & 4 & $30.92^{* *}$ & $26.53^{* *}$ & 9.1 & & & & & \\
\hline & $\mathrm{S}$ & 1 & 3.65 & 2.33 & $19.78^{* *}$ & & & & & \\
\hline & $\mathrm{P} \times \mathrm{S}$ & 4 & 6.17 & 3.04 & 3.23 & & & & & \\
\hline \multirow[t]{3}{*}{ August 2006} & $\mathrm{P}$ & 4 & & & & $17.38^{*}$ & 2.04 & 5.99 & 4.92 & $13.61^{*}$ \\
\hline & $\mathrm{S}$ & 1 & & & & $7.93^{*}$ & $30.02^{* *}$ & $7.49^{*}$ & 2.39 & 3.51 \\
\hline & $\mathrm{P} \times \mathrm{S}$ & 4 & & & & 0.62 & 1.40 & 0.83 & 2.48 & 4.03 \\
\hline \multirow[t]{3}{*}{ November 2006} & $\mathrm{P}$ & 4 & & & & 10.68 & 2.49 & 4.66 & & 2.60 \\
\hline & $\mathrm{S}$ & 1 & & & & $9.25^{*}$ & 3.49 & $10.21^{* *}$ & & $12.76^{*}$ \\
\hline & $\mathrm{P} \times \mathrm{S}$ & 4 & & & & 3.28 & 4.66 & 1.16 & & 10.78 \\
\hline
\end{tabular}

${ }^{*} p=0.017-0.001$.

** $p<0.001$.

\section{Appendix D.}

See Table D1. 
Table C1

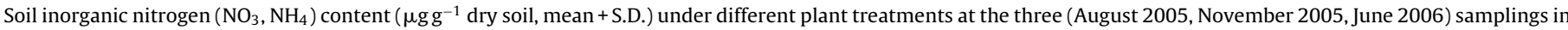

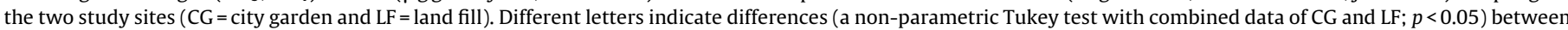
the plant treatments within a sampling time.

\begin{tabular}{|c|c|c|c|c|c|c|c|c|c|}
\hline \multirow[t]{2}{*}{ Soil nutrients } & \multirow[t]{2}{*}{ Plant treatments } & \multicolumn{2}{|l|}{ August 2005} & \multicolumn{3}{|c|}{ November 2005} & \multicolumn{3}{|l|}{ June 2006} \\
\hline & & CG & LF & CG & & LF & CG & & LF \\
\hline \multirow[t]{5}{*}{$\mathrm{NO}^{-}$} & Calluna and Picea & $2.1+0.96 .2+2.5$ & $0.8+0.90 .6+0.6$ & $5.4+2.2$ & $\mathrm{~b}$ & $0.2+0.1$ & $2.1+0.6$ & $\mathrm{~b}$ & $0.3+0.3$ \\
\hline & Lotus & & & $8.6+1.7$ & $\mathrm{a}$ & $7.9+5$ & $6.6+4.9$ & $\mathrm{a}$ & $11.1+4$ \\
\hline & Holcus & $2.1+0.9$ & $0.1+0.1$ & $2.8+0.4$ & b & $0.2+0.1$ & $4.3+3.0$ & $\mathrm{~b}$ & $0.4+0.2$ \\
\hline & Mixed & $3.6+0.5$ & $0.3+0.2$ & $6.5+2.2$ & $\mathrm{ab}$ & $0.4+0.1$ & $11.4+5.8$ & $\mathrm{a}$ & $8.5+2.8$ \\
\hline & commun. Weeded & $8.3+3.2$ & $1+0.7$ & $4.1+0.2$ & $\mathrm{~b}$ & $0.2+0.1$ & $3.8+0.6$ & $\mathrm{~b}$ & $0.7+0.2$ \\
\hline \multirow[t]{5}{*}{$\mathrm{NH} 4^{+}$} & Calluna and Picea & $3.7+1.4$ & $0.3+0.3$ & $1.0+0.4$ & $\mathrm{~b}$ & $2.1+0.6$ & $2.2+1$ & $\mathrm{~b}$ & $1.3+1.3$ \\
\hline & Lotus & $3.7+0.6$ & $0.7+0.7$ & $5.0+3.6$ & $\mathrm{a}$ & $5.3+0.3$ & $9.8+5.6$ & $\mathrm{a}$ & $4.1+3.9$ \\
\hline & Holcus & $3.6+1.3$ & $0.4+0.4$ & $2.2+1.7$ & $\mathrm{~b}$ & $2.5+1.1$ & $4.6+2.7$ & $\mathrm{a}$ & $3.8+5.5$ \\
\hline & & $4.9+0.9$ & $0.3+0.2$ & $2.6+0.8$ & $\mathrm{ab}$ & $3.1+1.1$ & $4.0+1.1$ & $\mathrm{a}$ & $4.3+0.5$ \\
\hline & Mixed community Weeded & $3.9+0.7$ & $0.7+0.7$ & $0.2+0.4$ & $\mathrm{~b}$ & $2.9+0.3$ & $0.4+0.6$ & $\mathrm{~b}$ & $0.7+0.7$ \\
\hline
\end{tabular}

Table D1

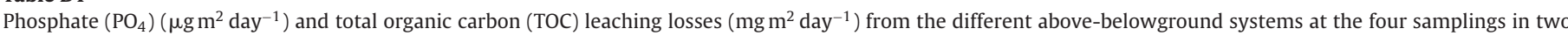
soil types (CG and LF).

\begin{tabular}{|c|c|c|c|c|c|c|c|c|c|}
\hline \multirow{2}{*}{$\begin{array}{l}\text { Leachates } \\
\mathrm{PO}_{4}{ }^{3-}\end{array}$} & \multirow{3}{*}{$\begin{array}{l}\text { Plant treatment } \\
\text { Calluna and Picea } \\
\text { Lotus }\end{array}$} & \multicolumn{2}{|c|}{ August 2005} & \multicolumn{2}{|c|}{ November 2005} & \multicolumn{2}{|c|}{ August 2006} & \multicolumn{2}{|c|}{ November 2006} \\
\hline & & & & $2.82+2.2$ & $0.19+0.13$ & 0 & $0.03+0.06$ & $1.56+0.7$ & $1.1+1.7$ \\
\hline & & & & $0.07+0.1$ & $0.3+0.1$ & $0.4+0.9$ & $0.2+0.2$ & $0.8+0.9$ & $0.06+0.06$ \\
\hline & Holcus & & & $2+0.9$ & $0.3+0.6$ & $0.6+0.1$ & $0.1+0.1$ & $0.9+0.4$ & $1+1.8$ \\
\hline & Mixed community & & & $3.3+2.8$ & $0.1+0.1$ & 0 & $0.04+0.1$ & $1.15+0.5$ & $0.1+0.1$ \\
\hline & Weeded & & & $4+1.7$ & $0.8+0.3$ & $0.2+0.6$ & $0.2+0.4$ & $1.2+1$ & $0.4+0.6$ \\
\hline \multirow[t]{5}{*}{ TOC } & Calluna Picea & $32+4$ & $12+11$ & & & $2.8+3.3$ & $1.4+2.7$ & & \\
\hline & Lotus & $40+24$ & $41+34$ & & & $3.5+3.3$ & $1.8+0.03$ & & \\
\hline & Holcus & $19+19$ & $18+15$ & & & $3.5+3.6$ & $0.04+0.03$ & & \\
\hline & Mixed community & $46+51$ & $33+24$ & & & $2.9+3.3$ & $2+3.6$ & & \\
\hline & Weeded & $21+11$ & $11+11$ & & & $0.2+0.3$ & $0.14+0.18$ & & \\
\hline
\end{tabular}

\section{Appendix E. Average number (individuals $\mathrm{g}^{-1}$ dry soil; mean + S.E.) of soil collembolans (open columns) and mites (solid columns) in November 2005. Different letters indicate differences between plant treatments (non-parametric Tukey test with combined data of CG and LF; $p<0.05$ ) separately for both faunal types.}

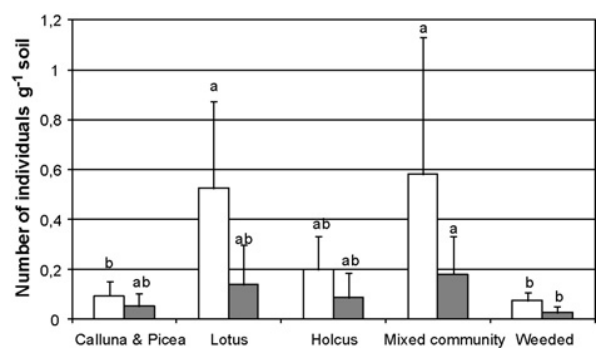

\section{References}

Abrahamsen, G., 1973. Biomass and body-surface area of populations of enchytraeidae and lumbricidae (Oligochaeta) in Norwegian coniferous forest soils. Pedobiologia 13, 28-39.

Antrop, M., 2004. Landscape change and the urbanization process in Europe. Landscape Urban Plan. 67, 9-26.

Bardgett, R.D., Mawdsley, J.L., Edwards, S., Hobbs, P.J., Rodwell, J.S., Davies, J., 1999 Plant species and nitrogen effects on soil biological properties of temperate upland grasslands. Funct. Ecol. 13, 650-660.

Bardgett, R.D., Bowman, W.D., Kaufmann, R., Schmidt, S.K., 2005. A tempora approach to linking aboveground and belowground ecology. Trends Ecol. Evol. 20, 634-641.

Benjamini, Y., Hochberg, Y., 1995. Controlling the false discovery rate: a practica and powerful approach to multiple testing. J. R. Stat. Soc. B 57, 289-300.

Berger, K.C., Truog, E., 1939. Boron determination in soils and plants using the quinalizarin reaction reaction. Industrial and engineering chemistry. Analytical Edition 11, 540-545.

Byrne, L.B., Bruns, M.A., Kim, K.C., 2008. Ecosystem properties of urban land covers at the aboveground-belowground interface. Ecosystems 11,1065-1077.
Bååth, E., Anderson, T.-H., 2003. Comparison of soil fungal/bacterial ratios in a pH gradient using physiological and PLFA-based techniques. Soil Biol. Biochem. 35, 955-963.

Carreiro, M.M., Howe, K., Parkhurst, D.F., Pouyat, R.V., 1999. Variation in quality and decomposability of red oak leaf litter along an urban-rural gradient. Biol. Fertil. Soils 30, 258-268.

Christian, E., Szeptycki, A., 2004. Distribution of Protura along an urban gradient in Vienna. Pedobiologia 48, 445-452.

Cheng, Z., Grewal, P.S., 2009. Dynamics of the soil nematode food web and nutrient pools under tall fescue lawns established on soil matrices resulting from common urban development activities. Appl. Soil Ecol. 42, 107-117.

Cheng, Z., Grewal, P.S., Stinner, B.R., Hurto, K.A., Hamza, H.B., 2008a. Effects of turfgrass management practices on soil nematode community and nutrient pools. Appl. Soil Ecol. 38, 174-184.

Cheng, Z., Richmond, D.S., Salminen, O.S., Grewal, P.S., 2008b. Ecology of urban lawns under three common management programs. Urban Ecosyst. 11, 177-195.

Coleman, D.C., Reid, C.P.P., Cole, C.V., 1983. Biological strategies of nutrient cycling in soil systems. In: MacFayden, A., Ford, E.D. (Eds.), Advances in Ecological Research, vol. 13. Academic Press, London, pp. 1-55.

De Deyn, G.B., Raajimakers, C.E., van Ruijven, J., Berendse, F., van der Putten, W.H. 2004. Plant species identity and diversity effects on different trophic levels of nematodes in the soil food web. Oikos 106, 576-586.

Frostegård, Å., Bååth, E., 1993. The use of phospholipid fatty acid analysis to estimate bacterial and fungal biomass in soil. Biol. Fertil. Soils 22, 59-65.

Frostegård, Å., Tunlid, A., Bååth, E, 1993. Phospholipid fatty acid composition, biomass, and activity of microbial communities from two soil types experimentally exposed to different heavy metals. Appl. Environ. Microb. 59, 3605-3617.

García, L.V., 2004. Escaping the Bonferroni iron claw in ecological studies. Oikos 105 657-663.

Grayston, S.J., Wang, S.Q., Campbell, C.D., Edwards, A.C., 1998. Selective influence of plant species on microbial diversity in the rhizosphere. Soil Biol. Biochem. 30 369-378.

Grime, J.P., 1974. Vegetation classification by reference to strategies. Nature 250 26-31.

Holtkamp, R., Kardol, P., van der Wal, A., Dekker, S.C., van der Putten, W.H., Ruiter P.C., 2008. Soil food web structure during ecosystem development after land abandonment. Appl. Soil Ecol. 39, 23-34.

Hooper, D.U., Chapin, F.S., Ewel, J.J., Hector, A., Inchausti, P., Lavorel, S., et al., 2005 Effects of biodiversity on ecosystem functioning: a consensus of current knowledge. Ecol. Monogr. 75, 3-35.

Innes, L., Hobbs, P.J., Bardgett, R.D., 2004. The impacts of individual plant species on rhizosphere microbial communities in soils of different fertility. Biol. Fertil. Soils 40, 7-13. 
Jiménez, J.J., Decaëns, T., Lavelle, P., 2008. C and N concentrations in biogenic structures of a soil-feeding termite and a fungus-growing ant in the Colombian savannas. Appl. Soil Ecol. 40, 120-128.

Kaye, J.P., McCulley, R.L., Burke, I.C., 2005. Carbon fluxes, nitrogen cycling, and soil microbial communities in adjacent urban, native and agricultural ecosystems. Glob. Change Biol. 11, 575-587.

Kardol, P., Newton, J.S., Bezemer, T.M., Maraun, M., van der Putten, W.H., 2009. Contrasting diversity patterns of soil mites and nematodes in secondary succession. Acta Oecol. 35, 603-609.

Klamer, M., Bååth, E., 2004. Estimation of conversion factors for fungal biomass

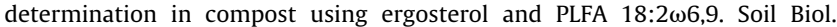
Biochem. 36, 57-65.

Knapp, S., Kühn, I., Schweiger, O., Klotz, S., 2008. Challenging urban species diversity: contrasting phylogenetic patterns across plant functional groups in Germany. Ecol. Lett. 11, 1054-1064.

Leckie, S.E., Prescott, C.E., Grayston, S.J., Neufeld, J.D., Mohn, W.W., 2004. Characterization of humus microbial communities in adjacent forest types that differ in nitrogen availability. Microb. Ecol. 48, 29-40.

Lorenz, K., Lal, R., 2009. Biogeochemical C and N cycles in urban soils. Environ. Int. $35,1-8$.

Macfadyen, A., 1961. Improved funnel-type extractors for soil arthropods. J. Anim. Ecol. 30, 171-184.

Marschner, P., Crowley, D., Yang, C.H., 2004. Development of specific rhizosphere bacterial communities in relation to plant species, nutrition and soil type. Plant Soil 261, 199-208.

McDonnell, M.J., Pickett, S.T.A., Groffman, P., Bohlen, P., Pouyat, R.V., Zipperer, W.C., Parmelee, R.W., Carreiro, M.M., Medley, K., 1997. Urban Ecosyst. 1, 21-36.

McIntyre, N.E., Rango, J., Fagan, W.F., Faeth, S.H., 2001. Ground arthropod community structure in a heterogeneous urban environment. Landscape Urban Plan. 52, 257-274.

Moore, J.C., Hunt, H.W., 1988. Resource compartmentation and the stability of real ecosystems. Nature 333, 261-263.

Moore, J.C., McCann, K., de Ruiter, P.C., 2005. Modeling trophic pathways, nutrient cycling, and dynamic stability in soils. Pedobiologia 49, 499-510.

Neher, D.A., Weicht, T.R., Moorhead, D.L., Sinsabaugh, R.L., 2004. Elevated $\mathrm{CO}_{2}$ alters functional attributes of nematode communities in forest soils. Funct. Ecol. 18, 584-591.

O'Connor, F.B., 1967. The enchytraeidae. In: Burges, A., Raw, F. (Eds.), Soil Biology. Academic Press, London, pp. 213-217.

Olsson, P.A., Bååth, E., Jakobsen, I., Söderström, B., 1995. The use of phospholipid and neutral lipid fatty-acids to estimate biomass of arbuscular mycorrhizal fungi in soil. Mycol. Res. 99, 623-629.

Olsson, P.A., 1999. Signature fatty acids provide tools for determination of the distribution and interactions of mycorrhizal fungi in soil. FEMS Microbiol. Ecol. 29, 303-310.

Paterson, E., Osler, G., Dawson, L.A., Gebbing, T., Sim, A., Ord, B., 2008. Labile and recalcitrant plant fractions are utilised by distinct microbial communities in soil: independent of the presence of roots and mycorrhizal fungi. Soil Biol. Biochem. 40, 1103-1113.

Pavao-Zuckerman, M.A., Coleman, D.C., 2005. Decomposition of chestnut oak (Quercus prinus) leaves and nitrogen mineralization in an urban environment. Biol. Fertil. Soils 41, 343-349.

Pavao-Zuckerman, M.A., Coleman, D.C., 2007. Urbanization alters the functional composition, but not taxonomic diversity, of the soil nematode community. Appl. Soil Ecol. 35, 329-339.

Pavao-Zuckerman, M.A., 2008. The nature of urban soils and their role in ecological restoration in cities. Restor. Ecol. 16, 642-649.

Pickett, S.T.A., Cadenasso, M.L., Grove, J.M., Nilon, C.H., Pouyat, R.V., Zipperer, W.C., et al., 2001. Urban ecological systems: linking terrestrial, ecological, physical and socioeconomic components of metropolitan areas. Annu. Rev. Ecol. Syst. 32, $127-157$.

Pieper, S., Weigman, G., 2008. Interactions between isopods and collembolans modulate the mobilization and transport of nutrients from urban soils. Appl. Soil. Ecol. 39, 109-126.
Pouyat, R., Groffman, P., Yesilonis, I., Hernandez, L., 2002. Soil carbon pools and fluxes in urban ecosystems. Environ. Pollut. 116, 107-118.

Ranta, E., Rita, H., Kouki, J., 1989. Biometria. Yliopistopaino, Helsinki, 325-326, 332.

Rooney, N., McCann, K., Gellner, G., Moore, J.C., 2006. Structural asymmetry and the stability of diverse food webs. Nature 442, 265-269.

Schaefer, V., 2009. Alien invasions, ecological restoration in cities and the loss of ecological memory. Rest. Ecol. 17, 171-176.

Siepel, H., 1994. Life-history tactis of soil microarthropods. Biol. Fertil. Soils 18, 263-278.

Spehn, E., Joshi, J., Schmid, B., Alphei, J., Körner, C., 2000. Plant diversity effects on soil heterotrophic activity in experimental grassland ecosystems. Plant Soil 224, 217-230.

Steinberg, D.A., Pouyat, R.V., Parmelee, R.W., Groffman, P.M., 1997. Earthworm abundance and nitrogen mineralization rates along urban-rural land use gradient Soil Biol. Biochem. 29, 427-430.

Stoeck, T., Krönckel, I., Duineveldz, G.C.A., Palojärvi, A., 2002. Phospholipid fatty acid profiles at depositional and non-depositional sites in the North Sea. Mar. Ecol. Prog. Ser. 241, 57-70.

Thompson, K., McCarthy, M.A., 2008. Traits of British alien and native urban plants. J. Ecol. 96, 853-859.

Tunlid, A., White, D.C., 1992. Biochemical analysis of biomass, community structure nutritional status, and metabolic activity of microbial communities in soil. In: Stotsky, G., Bollag, J.M. (Eds.), Soil Biochemistry. Dekker, New York, pp. 229261.

United Nations, 2007. World Urbanization Prospects: The 2007 Revision.

Viketoft, M., Bengtsson, J., Sohlenius, B., Berg, M., Petchey, O., Palmborg, C., HussDanell, K., 2009. Long-term effects of plant diversity and composition on soil nematode communities in model grasslands. Ecology 90, 90-99.

Vitousek, P.M., Mooney, H.A., Lubchenco, J., Melillo, J.P., 1997. Human domination on Earth's Ecosystems. Science. 277, 494-499.

Vuorinen, J., Mäkitie, O., 1955. The method of soil testing in use in Finland. Agrogeological Publications 63, 1-44.

Waite, T., Campbell, L., 2006. Controlling the false discovery rate and increasing statistical power in ecological studies. Ecoscience 13, 439442.

Wardle, D.A., 2002. Communities and ecosystems-linking the above and belowground components. In: Levin, S.A., Horn, H.S. (Eds.), Monographs in Population Biology, vol. 34. Princeton University Press, Princeton.

Wardle, D.A., Yeates, G.W., Williamson, W.M., Bonner, K.I., 2003. The response of a three trophic level soil food web to the identity and diversity of plant species and functional groups. Oikos 102, 45-56.

Williams, N.S.G., Morgan, J.W., McDonnell, M.J., McCarthy, M.A., 2005. Plant traits and local extinctions in natural grasslands along an urban-rural gradient. J. Ecol. 93, 1203-1213.

Yeates, G.W., Bongers, R., de Goede, R.G.M., Freckman, D.W., Georgeiva, S.S., 1993 Feeding habits in soil nematode families and genera an outline for soil ecologists. J. Nematol. 25, 315-331.

Zelles, R., 1999. Fatty acid patterns of phospholipids and lipopolysaccharides in the characterisation of microbial communities in soil: a review. Biol. Fertil. Soils 29 111-129.

Saara Vauramo is a PhD candidate in the Department of Environmental Sciences at University of Helsinki, Finland. Her PhD thesis focuses on studying the linkages between aboveground and belowground biota and their ecosystem ecologica consequences in disturbed urban soils

Heikki Setälä is a professor in urban ecosystem studies at the Department of Environmental Sciences, University of Helsinki, Finland. His professional activities involve exploring the links between biological diversity and ecosystem functioning/ecosystem services in natural and urban landscapes. A new approach in his research is using the quantity and quality of stormwaters as an indicator of ecosystem's ability to resist disturbances 